\title{
EVALUASI LAHAN PERSAW AHAN PADA TIGA DAERAH ALIRAN SUNGAI DI SUMATERA BARAT
}

\author{
Azwar Rasyidin \\ J urusan Tanah F akultas Pertanian U niversitas Andalas Padang
}

\begin{abstract}
s
Research on soils fertility of rice soils has been done on three catchment in West Sumatra province ie; Ulu Selo ( inland areas of selo river) at Tanah Datar district conducted three Kenagarian ( traditional village) Simpurut, Gurun, and Padang Laweh. Lembang catcment at Solok district is conducted ubo irrigation scheme ubo which divided as Ubo atas irrigation scheme and Sirukam. Sumpur cathment at East Pasaman District conducted three Kenagarian, Lundar, Petok and Kuamang. All of irrigation scheme located at agroclimatic zone C1 up to D2, with charaterize 2 or 3 consecutive wet month and 3 or 4 consecutive dry month. Soils were developed from volcanic parents materials. Rice soils of Ulu Selo shown lower $\mathrm{pH}$ value compared to the soils with land use is mixed garden, which some of the sampling point has shown the $\mathrm{pH}$ lower than 4. the rice soils of Lembang and Sumpur also shown the similar trend of $\mathrm{pH}$ but the value not so extremely like the soils from Ulu Selo. Related to the minimum value of carbon in rice soils is indicate that some of the rice soils in the research areas could be grouping as degraded land. The rice soils from Sumpur has high natural soil fertility which which shown on the natural reserved of nitrogen, phosphor and potassium. The soils condition could support the rice production up to $8 \mathrm{t} / \mathrm{ha} / \mathrm{GS}$ without additional nutrient. While soils from Ulu Selo shown lower content of phosphor. Based on this research author suggested to fertilizer program is better done based on the condition of soils itself. Even the natural soils fertility is high is not reccomended to use addtional artificials fertilizer.
\end{abstract}

Key words: cathment studies, natural soil fertility, rice production and land degradation.

\section{PENDUHULUAN}

Usaha untuk pemenuhan kebutuhan pangan dalam negeri dilaksanakan melalui proses peningkatan produksi padi, baik melalui peningkatan luas panen atau penambahan luas areal persawahan ataupun melakukan intensifikasi tanaman padi. Intensifiasi adalah usaha yang mengenalkan program penggunaan bibit unggul, yaitu varietas unggul yang tahan terhadap hama dan respon terhadap pemupukan sehingga memberikan hasil yang maksimal. Penggunaan bibit unggul dibarengi dengan progam pemupukan, pengairan, pemberantasan hama, dan perbaikan cara bercocok tanam.

Sebagai suatu kegiatan crash program peningkatan produksi sangat praktis, terutama dalam mengganti unsur hara yang terbawa tanaman. Pemupukan menjadi suatu program utama. Berhubung karena informasi mengenai sumber daya lahan yaitu tentang sifat kimia dan fisika tanah sangat terbatas, maka untuk mensukseskan program pemupukan dilakukan penyeragaman yaitu dengan mengeluarkan nilai rekomendasi umum pemupukan.

Rekomendasi umum pemupukan dapat berarti bahwa nilai hara yang dikandung oleh setiap lahan adalah seragam.Hal itu sangat bertentangan dengan sifat tanah itu sendiri. Pengelompokan tanah kedalam taxa disebabkan karena secara alamiah tanah itu berbeda dan perbedaan hakiki terutama disebabkan oleh faktor faktor pembentuk tanah dan tingkat perkembangan tanah.

Di wilayah Sumatera Barat sentra produksi padi terletak pada beberapa daerah aliran sungai (DAS) seperti DAS ulu Selo di Kabupaten Tanah Datar, DAS Lembang di Kabupaten Solok dan DAS Sumpur di Lubuak Sikaping Kabupaten pasaman. Secara fisik ketiga daerah tersebut berada di lereng gunung merapi yang relatif subur. Walaupun demikian karena ketiganya adalah areal tanaman padi intensifikasi, maka 
ketiga areal tersebut tetap di perlakukan dengan rekomendasi umum pemupukan.

Untuk melihat kondisi riil di ketiga daerah pertanaman padi tersebut dilakukan evaluasi terhadap lahan persawahan di wilayah itu melalui suatu kegiatan penelitian tentang sifat kimia tanah sawah. Penelitian tersebut dilakukan dalam spot spot penelitian seperti penelitian Rasyidin (2002), Tim Feasibility study irigasi Ubo (1996) Evaluasi kesuburan tanah sawah di DAS Ulo Selo yang di lakukan sebagai penelitian tugas akhir, Ade Intan Kemala ( 2001) Fitria Rachmawati ( 2001), Evaluasi kesuburan lahan sawah di DAS Sumpur Pasaman, Upit Fitriani ( 2002) dan Zulfa Hanim ( 2002) tugas akhir mengenai kelarutan Fe Afridia Husna (2003) dan Resmi Sari pribadi ( 2003) penelitian tanah sawah di hulu batang Mangau. Tulisan ini merupakan rangkuman dan pembahasan tentang posisi lahan persawahan dalam suatu daerah aliran sungai serta nilai kesuburan alamiah tanah sawah.

\section{BAHAN DAN METODA}

\section{Kondisi daerah penelitian}

DAS ulu Selo berlokasi di kabupaten Tanah datar, mencakup tiga kenagarian yaitu Simpurut, Gurun dan Padang Laweh. Secara fishiografis ketiga kenagarian ini berada pada tiga fihsiografi yang berbeda. Yaitu Lereng bawah volcanic, lereng tengah volcanic dan lereng atas volcanic (Desaunet, 1977) untuk kenagarian Simpurut, Gurun dan Padang Laweh. Rata rata curah hujan tahunan 2048mm, dengan zona iklim pertanian D2 menurut Oldelman. Daerah ini memiliki tiga bulan kering, yakni pada bulan Juni, Juli dan Agustus dengan curah hujan $<100 \mathrm{~mm}$. Tanah di daerah penelitian berkembang dari bahan tuff vulkan.

DAS Sumpur berlokasi di Kabupaten pasaman yang mencakup tiga kenagarian dalam wilayah irigasi Panti Rao, yaitu Petok, Lundar dan Kuamang. Iklim di daerah ini berdasarkan stasiun Lubuk Sikaping tergolong kedalam zona E3 iklim pertanian Oldelman, rata rata curah hujan tahun $1757 \mathrm{~mm}$ memiliki 1 bulan basah dan 3 bulan kering yaitu Juni, Juli dan Agustus.
Tanah di daerah ini berkembang dari bahan aluvium

DAS Lembang berlokasi di lereng gunung Talang, termasuk ke dalam daerah irigasi Ubo yang dibagi atas Ubo atas pada fishiografi Lereng Atas Volcanik, Ubo tengah pada lereng tengah volkanik dan Ubo Hilir yang mencakup daerah Lereng bawah volkanik. Tanah berkembang dari Tuff volcan. Daerah irigasi Ubo memiliki dua type iklim yaitu zona Agroklimat C1 berdasarkan stasiun pengamat hujan Alahan Panjang dengan rata rata curah hujan tahunan $2351 \mathrm{~mm}$ dan zona Agroklimat E2 berdasarkan stasiun pengamat hujan Solok dengan rata rata curah hujan tahunan $2141 \mathrm{~mm}$.detail kondisi daerah penelitian dapat dilihat pada peta 1 .

Wilayah DAS Sumpur dan DAS Lembang selalu mendapat tambahan bahan baru, gunung Talang dalam periode 5 sampai 10 tahun sering mengeluarkan abu kepundan. Wialayah DAS sumpur setiap tahun mendapat endapan baru dari wilayah G.sorik Merapi. Berbeda dengan DAS ulu Selo yang hampir tidak mendapat bahan tambahan baru, tanahnya menjadi matang, sedangkan pada dua wilayah DAS yaitu Lembang dan Sumpur, tanahnya selalu muda, karena proses erosi dan pencucian diimbangi oleh penambahan bahan baru (Wakatsuki et al 1986).

Sampel tanah dan analisis

Pengambilan sampel didasarkan kepada sequence topografi pada setiap satuan fishiografi pada DAS Ulu Selo dan DAS Lembang yang berada pada sistim volkanis. Sampel diambil pada lereng bawah volkanis (VLS), lereng tengah volkanis (VMS) dan lereng atas volkanis ( VUS). Pada setiap satuan fishiografi diambil 11 titik pengambilan sampel, jumlah sampel untuk DAS lembang lebih sedikit bila di bandingkan dengan kedua DAS yang lain. Pada sistim Aluvial, pengambilan dilakukan di daerah hulu dan hilir, dari batang Sumpur, lokasi pengambilan sampel tersebar kedalam tiga kenagarian yang berada pada aliran batang Sumpur. Pengambilan sampel dilakukan dengan membuat transect dari tanggul sungai ke arah dataran pelimbahan, 
pengambilan sampel diusahakan memotong setiap satuan lahan. Sampel tanah diambil dari dua kedalaman yaitu $0-20 \mathrm{~cm}$ dan $20-$ $40 \mathrm{~cm}$. Sebagai pembanding juga dilakukan pengambilan sampel tanah pada daerah yang tidak disawahkan atau lahan kebun yang berdekatan dengan sawah.

Analisis dilakukan terhadap $\mathrm{pH} \mathrm{H}_{2} \mathrm{O}$ 1:5 dan $\mathrm{pH} \mathrm{KCl}$ dengan metoda elektrometrik ( MC Lean 1987), $\mathrm{N}$ total metoda (Kjedhal Bremner and Mulvaney,
1987), P tersedia dengan metoda Bray II (Olsen and Sommer 1987), C organik dengan metoda Wakley and Black( Nelson,D.W. and Sommer L.E, 1987) $\mathrm{K}, \mathrm{Ca}, \mathrm{Mg}$, dan $\mathrm{Na}$ dengan metoda pencucian dengan ammonium acetat ( Thomas 1987) KTK tanah dengan metoda pencucian dengan ammonium acetat $1 \mathrm{~N} \mathrm{pH}$ 7 ( Rhoades 1987), BV dengan metoda gravimetric.

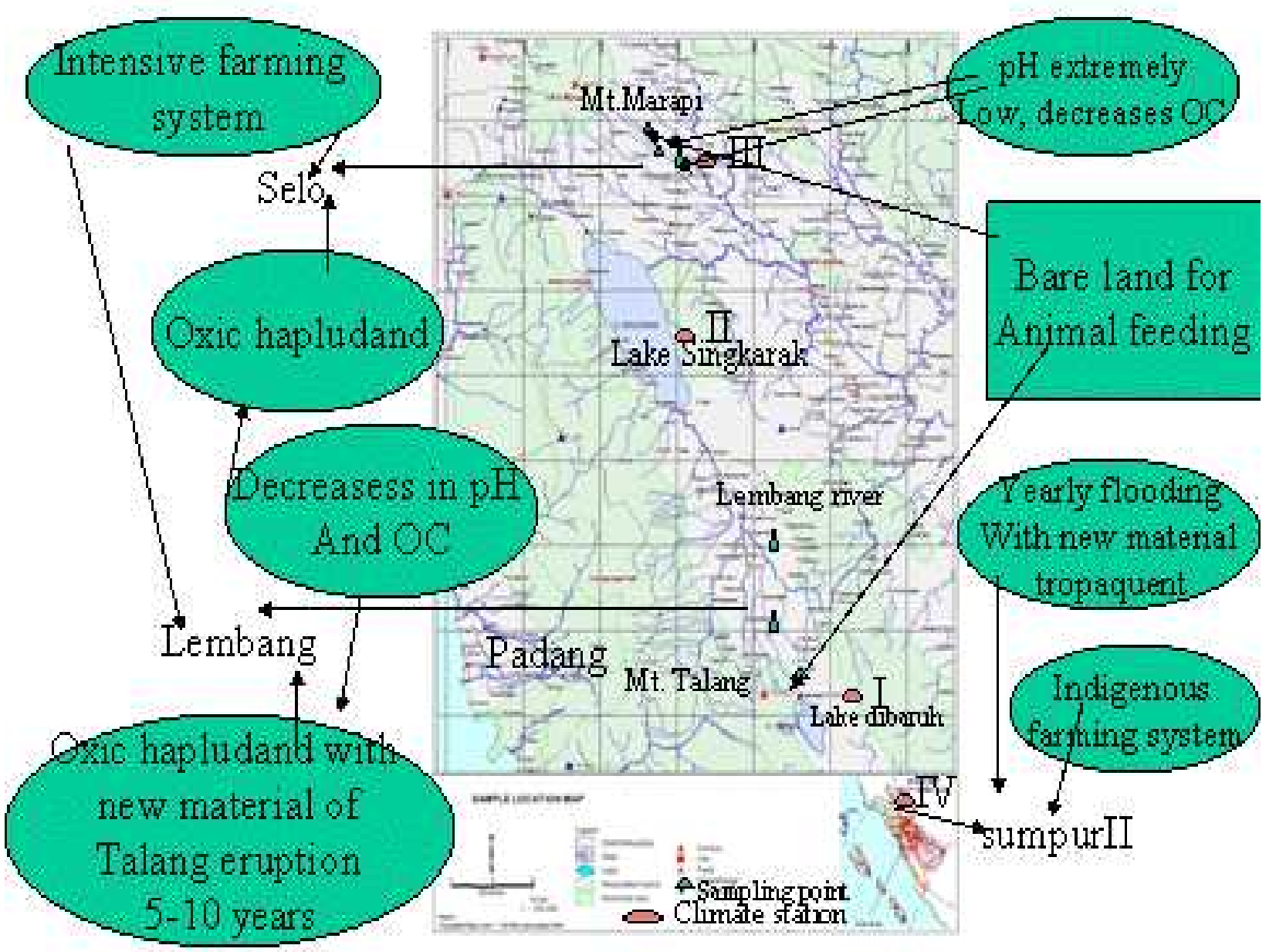

Figure 1. DAS Ulu Selo, DAS Lembang dan DAS Sumpur 


\section{HASIL DAN PEMBAHASAN}

Tanah pada DAS Ulu Selo dan DAS Lembang yang berlokasi pada sistim fihiografi vulkanis dapat dikelompokan kedalam oxic hapludand, sedangkan tanah di DAS Sumpur adalah Typik Tropaquent. Iklim di masing masing DAS dapat dilihat pada tabel 1.

Dari tabel di atas dapat dilihat bahwa DAS Lembang memiliki spesifikasi gradien aliran yang tajam yaitu beda tinggi antara DAS dibagian Hulu dan daerah hilir di dataran lereng bawah volcanik adalah $1000 \mathrm{~m}$. Perbedaan elevasi ini memungkinkan terjadinya perbedaan suhu rata rata harian kira kira $6^{\circ} \mathrm{C}$. Perkiraan ini didasarkan kepada teori Braak bahwa setiap kenaikan $100 \mathrm{~m}$ maka suhu udara akan turun $0.6^{\circ} \mathrm{C}$ ( Moor, Van Baren 1972). Perbedaan zona iklim pertanian cukup tegas yaitu D1 dan E2. hal itu menunjukkan bahwa terdapat perbedaan rata rata curah hujan tahunan hampir $1000 \mathrm{~mm}$

Dari data curah hujan tahunan tersebut terlihat bahwa ketiga DAS yang dipilih berada dalam wilayah zona hujan E2 sampai D1. wilayah yang terletak di pegunungan menunjukkan jumlah hari hujan dan curah hujan lebih tinggi dibandingkan dengan daerah dataran rendah di bawahnya. Kondisi seperti ini akan membawa pengaruh pada sifat dan ciri tanah yang salah satunya adalah bahan organik tanah.

Nilai karbon tanah yang dipersawahkan berbeda dengan nilai karbon tanah yang tidak dipersawahkan. Lahan kebun relatif tidak diolah secara intensif, umumnya ditanami dengan bermacam tanaman ( polikultur) sebagai suatu ciri dari perkebunan rakyat. Pola ini lebih umum dikenal sebagai kebun campuran. Lahan sawah umumnya diolah sangat intensif baik untuk ditanami dengan padi ataupun ditanami dengan tanaman palawija.

Data pada tabel 2 menunjukkan bahwa nilai karbon untuk kedalam $20 \mathrm{~cm}$ bervariasi untuk masing masing sawah pada masing masing DAS. Nilai rata rata karbon pada DAS ulu Selo di lereng atas vulkanik lebih tinggi dibandingkan dengan nilai rata rata yang dimiliki oleh DAS Sumpur ataupun DAS lembang dengan nilai $8.23 \mathrm{KgC.m}-{ }^{2}$ lebih tinggi bila dibandingkan dengan tanah pada fishiografi yang sama di DAS lembang $6.58 \mathrm{Kg} \mathrm{C.m}^{2}$. lahan sawah yang berada

Tabel 1. Rata Rata Curah Hujan dan Hari hujan pada DAS Ulu Selo, DAS Lembang dan DAS Sumpur Pasaman

\begin{tabular}{|c|c|c|c|c|c|c|c|c|c|c|c|c|c|c|c|c|}
\hline \multirow{3}{*}{ 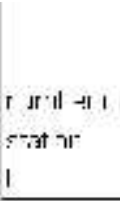 } & \multicolumn{16}{|c|}{ 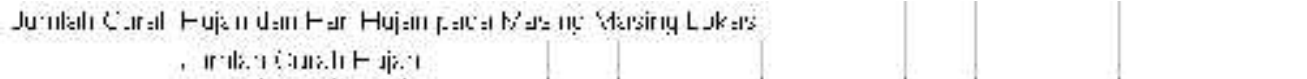 } \\
\hline & -il tlill & $\begin{array}{l}1+\mu \\
1 \%\end{array}$ & \multirow{2}{*}{ 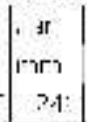 } & \multirow{2}{*}{$\left|\begin{array}{c}-4 t \\
173 \mid\end{array}\right|$} & $\mid$ biar the il & \multirow{2}{*}{$\left|\begin{array}{l}\because x \mid \\
17>\mid\end{array}\right|$} & \multirow{2}{*}{\begin{tabular}{|l}
111 \\
17
\end{tabular}} & \multirow{2}{*}{$\begin{array}{l}\text { III: } \\
\text { 3ii }\end{array}$} & \multirow{2}{*}{$\begin{array}{l}\text { |if !1: } \\
\text { i) }: 39\end{array}$} & \multirow{2}{*}{$\begin{array}{l}S i t|| \\
|F|\end{array}$} & \multirow{2}{*}{\begin{tabular}{|l|}
$\mid \because n: 1$ \\
$z 1: \mid$
\end{tabular} \mid} & \multirow{2}{*}{$\begin{array}{l}\text { r. } 10 \\
\text { ? ? ? }\end{array}$} & \multirow{2}{*}{$\begin{array}{l}\text { ip : } \\
? 10 \mathrm{i}\end{array}$} & \multirow{2}{*}{ 11:- } & \multirow{2}{*}{\multicolumn{2}{|c|}{ 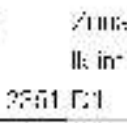 }} \\
\hline & 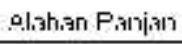 & |Aา & & & ख़ा & & & & & & & & & & & \\
\hline II & tกnר $F$ al 1 & $113 \Gamma$ & ? & 10整 & 8fi 2ती & 1.27 & 53 & in & $\cdot \mathrm{n}$ & If & 237 & 277 & 170 & & $16 \div 5$ & $\mathrm{FI}$ \\
\hline III & Solot: & sis & $25]$ & 135 & $219 \quad 250$ & $1<\varepsilon$ & 13 & $i c$ & 23 & 142 & $2 \cdot 5$ & $2[3$ & 237 & & $21<1$ & {$[\because 1$} \\
\hline Bi & Singkaral: & 538 & {$[7$} & 179 & $50 \quad$ IC 6 & 1.15 & 77 & 52 & 00 & 140 & $13 E$ & $8 ?$ & 235 & & IE6E & {$[2$} \\
\hline 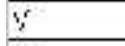 & Eurral & $4 \exists C$ & . & 151 & $50 \quad 100$ & 125 & E5 & 56 & 90 & 142 & 178 & $\cdot 9 \mathrm{~g}$ & 27 & & $175 \overline{7}$ & $\sqsubset 1$ \\
\hline 89 & 7 $\varepsilon$ nbat $\varepsilon 1$ & 678 & 273 & 141 & $? 16 \quad 156$ & $13^{7}$ & $E ?$ & 77 & 64 & 116 & 130 & $E$ & 176 & & 1658 & {$[2$} \\
\hline $3: 11$ & Jatusanylar & $43 \mathrm{C}$ & 944 & 132 & $200 \quad 2 C 0$ & $1]^{7}$ & 13 & 70 & 17 & 140 & $\therefore \cdot \mathrm{C}$ & $i ?$ & 25 & & $2 \mathrm{C} 1 \mathrm{E}$ & {$[1$} \\
\hline \multicolumn{17}{|c|}{ 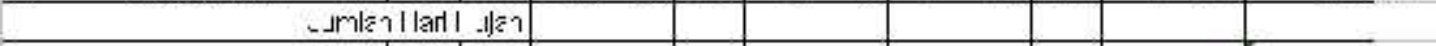 } \\
\hline & nlahan Panjan & 1430 & 13 & 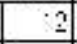 & 15 & 13 & 3 & 0 & 11 & 12 & $\mathrm{E}$ & 15 & 6 & & 160 & \\
\hline & $\therefore$ ul.」 ヒ.Ir.I & $11 \mathrm{st}$ & 12 & $\mathrm{U}$ & $13 \quad 1 \div$ & 11 & $i$ & 6 & y & $1:$ & 3 & $1 i$ & 5 & & $1 \div \mathrm{L}$ & \\
\hline & Suluk. & $\therefore t$ & 16. & $\because \ddot{\prime \prime}$ & $1:=4 \quad 14.1$ & $\because U:=$ & 3 & 6.0 & t. & $1 \div$. & $\div 2$ & $14 . i$ & $15 . \mathrm{U}$ & & $14=1$ & \\
\hline & Sirı!̣k:ar $\leq k$ & 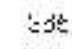 & $1: b$ & $i .8$ & $\varepsilon y \quad 10$ & ' & 4.2 & & $\leqslant 8$ & t.3 & 1.1 & 11 & 11.- & & $1 \mathrm{~J} / 4$ & \\
\hline & IIII :II: & $1-11$ & 1:A.1 & प्र.प & $\begin{array}{llll}11 & B & 1 & 1.8\end{array}$ & 81 & h.' & ก.. & in & $11 . .9$ & -1.4 & $1: 2:$ & 1 i.n & & $1.1 \%$ & \\
\hline & $S_{n=n}$ nlo.at: $=9$ & $2 i$ & $\because ?$ & 'li & $\because \because 14$ & 14 & -1 & & y & $11 i$ & ' & $1:$ & & & $14 !$ & \\
\hline & Fiat 15 an -qkar & 1कir & 11 & 2 & 12 & 9 & 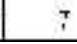 & ii & 8 & 11 & $\because$ & 13 & $\because$ & & $13 r$ & \\
\hline
\end{tabular}


Table 2. Nilai karbon lapisan atas dan lapisan bawah tanah sawah

\begin{tabular}{|l|l|l|l|l|l|l|}
\hline DAS & Lokasi & kedalaman & KgC.m & maksimum & minimum & kebun \\
\hline Selo & Padang lawas & $0-20$ & 8.23 & 16.12 & 3.49 & 10.2 \\
\hline & $(\mathrm{n}=11)$ & $20-40$ & 3.68 & 9.57 & 1.25 & 4.41 \\
\hline & Gurun & $0-20$ & 5.78 & 9.37 & 3.55 & 5.67 \\
\hline & $(\mathrm{n}=11)$ & $20-40$ & 5.48 & 12.14 & 2.65 & 4.13 \\
\hline & Simpurut & $0-20$ & 6.68 & 11.58 & 2.41 & 14.37 \\
\hline & & $20-40$ & 5.65 & 7.36 & 3.03 & 8.1 \\
\hline Sumpur & petok & $0-20$ & 6.1 & 8.9 & 2.33 & 9.32 \\
\hline & (n=11) & $20-40$ & 7.08 & 11.5 & 5.52 & 6.29 \\
\hline & Lundar & $0-20$ & 6.96 & 12.49 & 4.29 & 6.22 \\
\hline & (n=11) & $20-40$ & 7 & 12.96 & 5.3 & 7.74 \\
\hline & Kuamang & $0-20$ & 4.74 & 7.02 & 2.9 & 6.57 \\
\hline & (n=11) & $20-40$ & 5.99 & 7.5 & 3.7 & 6.97 \\
\hline & ubo atas & $0-20$ & 6.58 & 10.98 & 4.35 & 16.71 \\
\hline & & $20-40$ & 5.25 & 8.9 & 2.1 & 9.88 \\
\hline & Sirukam & $0-20$ & 7.03 & 8.5 & 2.98 & 13.3 \\
\hline & & $20-40$ & 3.69 & 4.8 & 2.4 & 6.47 \\
\hline & & & & & & \\
\hline
\end{tabular}

di daerah dengan fihiografi aluvial tidak menunjukkan variasi yang menyolok antara ketiga lokasi juga antara nilai karbon di lahan sawah dengan nilai karbon pada tanah kebun. Data dari Lundar memperlihatkan nilai yang hampir sama dengan nilai rata rata yaitu $6.96 \mathrm{Kg} . \mathrm{C} . \mathrm{m}^{-2}$. dan $6.22 \mathrm{kgC} . \mathrm{m}^{-2}$ untuk rata nilai karbon pada lahan sawah dibandingkan dengan lahan kebun.

Variasi dalam nilai karbon tanah sawah yang sangat menyolok di observasi pada tanah yang berlokasi pada lereng volkanik baik di lereng atas ataupun lereng bawah.Kenagarian Padang Laweh misalnya memperlihatkan range yang sangat meyolok antara nilai maksimum dan minimum dari 11 titik pengamatan yaitu $16.12 \mathrm{~kg} \mathrm{C} . \mathrm{m}^{-2}$, dan $3.49 \mathrm{~kg} \mathrm{C} . \mathrm{m}^{-2}$. nilai maksimum pada tanah sawah itu jauh melebihi nilai pengukuran karbon pada tanah kebun yaitu $10.2 \mathrm{~kg} \mathrm{C} . \mathrm{m}^{-2}$. kondisi lapangan seperti ini berkaitan erat dengan pola pertanian padi sawah di daerah yang bersangkutan.

Kenagarian Padang Laweh dikenal memiliki ternak kerbau dan ternak sapi.
Pada masa musim kering sehabis panen palawija sapi dan kerbau tersebut di tempatkan pada lahan sawah. Dengan kata lain lahan sawah berobah fungsi menjadi padang pengemba laan. Justru karena itu lahan sawah memiliki nilai maksimum yang melebih nilai karbon pada lahan kebun. Data tersebut juga menunjukkan bahwa kodisi lahan kebun di kenagarian Padang Laweh sudah mengalami degradasi. Hal ini tentunya bila dibandingkan dengan data pada tanah oxic hapludand dari wilayah sekitar gunung Merapi yang memiliki nilai karbon $17-20 \mathrm{~kg} \mathrm{C.m} \mathrm{m}^{-2}$ atau dalam range rata

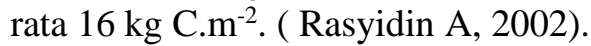

Pola penyebaran karbon dalam profil memperlihatkan bahwa nilai karbon akan menurun dengan bertambahnya kedalaman. Penumpukan karbon terlihat pada epipedon melanik. Adanya range data yang besar pada setiap kedalaman dan setiap DAS adalah suatu indikasi bahwa perlakuan petani padi sawah terhadap lahannya juga berbeda, terutama dalam tata cara mengelola bahan organik tanah. 
$\mathrm{pH}$ tanah

$\mathrm{pH}$ tanah dan bahan organik tanah tergolong kedalam faktor yang mempengaruhi penciri kesuburan tanah disamping faktor lain seperti KTK liat, Kejenuhan basa, dan total kation ( Sys et al 1993). pH tanah sawah disamping dipengaruhi oleh proses pengenangan (Ponamperuma 1978) juga dipengaruhi oleh unsur yang ditambahkan kedalam tanah. Penambahan unsur seperti $\mathrm{NH}_{4}^{+}$mempunyai kemungkinan untuk memberikan reaksi memasamkan tanah karena adanya pertukaran ion dengan $\mathrm{H}^{+}$pada waktu serapan hara oleh akar tanaman ( Brady, 1992). Pemberian pupuk kimia dalam jangka waktu yang lama membawa perubahan kimia pada ciri kimia tanah sawah.pH tanah sawah di Indonesia khususnya di Pulau Jawa sebelum intensifikasi berkisar antara 5.4 6.8 di lapisan atas ( Soeprartohardjo and Suhardjo, 1978). Pada daerah yang tidak memiliki data maka data $\mathrm{pH}$ dari lahan kebun yang berdampingan dan belum diolah secara intensif dapat di pedomani untuk melihat perubahan akibat dari penggenangan dan pengeringan dan perlakuan yang diberikan terhadap lahan sawah. Kondisi kemasaman tanah pada persawahan di tiga DAS tersebut dapat dilihat pada tabel 3.

Persawahan di DAS Ulu Selo memperlihatkan bahwa telah terjadi perubahan $\mathrm{pH}$ yang tajam pada lapisan tanah atas pada posisi lereng bawah dan lereng tengah vulkanik yang menunjukkan nilai dibawah 4, secara nilai rata-rata $\mathrm{pH}$ pada lereng tengah dan lereng bawah berada pada nilai di bawah 5. Kondisi ini berbeda dengan DAS Sumpur dan DAS Lembang yang menunjukkan nilai $\mathrm{pH}$ relatif normal.

Daerah irigasi Panti Rao yang mencakup Lundar, Kuamang dan Petok mengalami proses banjir setiap setahun. endapan banjir ini membawa hanyutan bahan dari gunung Sorik Merapi. Bahan aluvium tersebut diduga menyebabkan kondisi lahan di DAS Sumpur selalu segar dan $\mathrm{pH}$ berada dalam keadaan netral. Faktor kedua yang menyebabkan tidak ditemui perubahan $\mathrm{pH}$

Tabel 3. Nilai pH lapisan atas dan bawah tanah sawah pada beberapa lokasi

\begin{tabular}{|l|l|l|l|l|l|l|}
\hline DAS & Lokasi & kedalaman & $\mathrm{pH}$ & maksimum & minimum & kebun \\
\hline Selo & Padang lawas & $0-20$ & 5.15 & 5.51 & 4.41 & 6.28 \\
\hline & $(\mathrm{n}=11)$ & $20-40$ & 5.69 & 6.32 & 5.21 & 5.22 \\
\hline & Gurun & $0-20$ & 4.68 & 5.21 & 3.96 & 5.51 \\
\hline & $(\mathrm{n}=11)$ & $20-40$ & 5.5 & 6.19 & 4.58 & 4.97 \\
\hline & Simpurut & $0-20$ & 4.75 & 5.6 & 3.94 & 5.6 \\
\hline & & $20-40$ & 5.76 & 6.37 & 5.04 & 5.03 \\
\hline Sumpur & petok & $0-20$ & 5.95 & 6.57 & 5.47 & 6.07 \\
\hline & $(\mathrm{n}=11)$ & $20-40$ & 6.3 & 6.69 & 5.89 & 6.4 \\
\hline & Lundar & $0-20$ & 5.69 & 6.28 & 5.17 & 7.07 \\
\hline & $(\mathrm{n}=11)$ & $20-40$ & 5.67 & 6.19 & 5.08 & 6.03 \\
\hline & Kuamang & $0-20$ & 5.79 & 6.18 & 5.1 & 5.79 \\
\hline & $(\mathrm{n}=11)$ & $20-40$ & 5.21 & 6.24 & 4.31 & 6.11 \\
\hline & ubo atas & $0-20$ & 5.17 & 6.1 & 4.7 & 5.93 \\
\hline & & $20-40$ & 5.5 & 6 & 5.2 & 5.82 \\
\hline & Sirukam & $0-20$ & 5.3 & 5.94 & 4.8 & 4.5 \\
\hline & & $20-40$ & 5.6 & 6.26 & 5.2 & 4.1 \\
\hline
\end{tabular}


adalah kebiasaan dari petani di DAS Sumpur yang tidak menyukai penggunaan bahan kimia pertanian.

DAS lembang dipengaruhi oleh bahan erupsi G.Talang yang menutupi lahan tersebut dalam periode 5tahun sekali atau pada periode yang lebih pendek. DAS Lembang yang berada dalam Irigasi Bandar UBO merupakan areal padi intensifikasi . Petani di daerah ini umumnya menggunakan rekomendasi umum pemupukan yang dianjurkan oleh Dinas pertanian Tanaman pangan yaitu penggunaan pupuk Urea, TSP dan $\mathrm{KCl}$ sebanyak $250 \mathrm{~kg}$ urea, $100 \mathrm{~kg}$ TSP, dan $100 \mathrm{~kg} \mathrm{KCl}$.

DAS Lembang menunjukkan azas anomali penggunaan pupuk kimia yang tidak membawa pengaruh jelek pada lahan persawahan. Kondisi ini adalah disebabkan daerah ini secara rutin mendapat tambahan bahan baru berupa erupsi gunung Talang. Berbeda dengan DAS Ulu Selo yang relatif tidak mendapat pengaruh dari kegiatan aktifitas vulkanis, dan sedimentasi. Tanah di DAS ini memperlihatkan kondisi $\mathrm{pH}$ yang tidak sesuai dengan tanaman padi sawah. Yaitu nilai $\mathrm{pH}$ kecil dari 4, yaitu pada nilai $\mathrm{pH} 3.96$, dan nilai $\mathrm{pH} 3.94$ pada beberapa titik di Gurun dan Simpurut.
Pada umumnya dilaporkan oleh peneliti bahwa tanah Aluvial dan Andosol relatif lebih subur bila dibandingkan dengan tanah tanah yang lain. Kedua tanah ini diketahui memiliki cadangan hara yang memadai. Hasil analisa tanah yang kemudian dikonversi menjadi cadangan hara dalam bentuk $\mathrm{kg} / \mathrm{ha}$ dengan menggunakan faktor bulk density, dan tebal horizon yang dikalikan dengan hasil analisis lab berupa $\mathrm{meq} / 100$ gram tanah ataupun dalam $\mathrm{mg} / \mathrm{kg}$. Evaluasi nilai riil dari cadangan hara dibandingkan dengan jumlah unsur hara yang terangkut panen adalah cara yang relatif baik untuk menentukan jumlah unsur yang harus ditambahkan kepada tanah tersebut ( Sys et al, 1993). Cadangan hara di DAS Ulu Selo sebagai representasi tanah andisol dan dan Sumpur sebagai representasi tanah entisol disajikan pada tabel 4.

Kedua DAS diatas memperlihatkan kaitan dengan bahan induk vulkanik yang kaya akan unsur kalium. Hal itu dapat dilihat dari cadangan hara $\mathrm{K}_{2} \mathrm{O}$ di lapisan atas maupun lapisan bawah yang mencapai nilai antara 181 sampai $650 \mathrm{~kg} / \mathrm{ha}$. Nilai $\mathrm{K}_{2} \mathrm{O}$. Simpurut yang berada pada posisi lereng bawah vulkanik menunjukkan nilai terendah yaitu $181 \mathrm{~kg}$ dilapisan atas dan $218 \mathrm{~kg}$ di

Tabel 4. Cadangan hara lapisan tanah atas dan bawah subdas Ulu Selo dan DAS Sumpur

\begin{tabular}{|c|c|c|c|c|c|c|c|}
\hline \multirow[t]{2}{*}{ lokasi } & \multirow[t]{2}{*}{ kedalaman } & \multicolumn{2}{|c|}{$\begin{array}{l}\text { N kg.ha- } \\
1\end{array}$} & \multirow{2}{*}{$\begin{array}{l}\mathrm{P}_{2} \mathrm{O}_{5} \mathrm{~kg} \cdot \mathrm{ha}^{-1} \\
\text { rata rata }\end{array}$} & \multirow{2}{*}{$\mathrm{sd}$} & \multirow{2}{*}{$\begin{array}{l}\mathrm{K}_{2} \mathrm{O} \\
\text { kg.ha }{ }^{-1} \\
\text { rata rata }\end{array}$} & \multirow[b]{2}{*}{$\mathrm{sd}$} \\
\hline & & rata rata & sd & & & & \\
\hline \multirow[t]{2}{*}{ Pd Laweh } & $0-20$ & 255 & 54.95 & 58.27 & 12.63 & 431.9 & 173.22 \\
\hline & $20-40$ & 170 & 67.62 & 99.9 & 19.35 & 557 & 221.65 \\
\hline \multirow[t]{2}{*}{ Gurun } & $0-20$ & 255.36 & 97.64 & 23.16 & 6.09 & 280.36 & 204.07 \\
\hline & $20-40$ & 186.64 & 65.22 & 30.1 & 6.6 & 352.36 & 251.24 \\
\hline \multirow[t]{2}{*}{ Simpurut } & $0-20$ & 179.55 & 61.48 & 58.73 & 17.47 & 181.18 & 96.24 \\
\hline & $20-40$ & 136.64 & 49.61 & 77.27 & 18.29 & 218.36 & 179.45 \\
\hline \multirow[t]{2}{*}{ Lundar } & $0-20$ & 363 & 288 & 198 & 89 & 571 & 127 \\
\hline & $20-40$ & 241 & 122.51 & 249.73 & 88.13 & 684.09 & 151.54 \\
\hline \multirow[t]{2}{*}{ petok } & $0-20$ & 290 & 160 & 169 & 82 & 318 & 141 \\
\hline & $20-40$ & 364.91 & 176.41 & 209.91 & 80.6 & 411.91 & 149.77 \\
\hline \multirow[t]{2}{*}{ Kuamang } & $0-20$ & 261 & 164 & 188 & 73 & 469 & 115 \\
\hline & $20-40$ & 211.27 & 85.91 & 257.18 & 73.66 & 650.36 & 138.05 \\
\hline
\end{tabular}


lapisan bawah. Tanah di DAS sumpur yang berkembang dari bahan aluvium G.Sorik Merapi memperlihatkan jumlah cadangan hara yang hampir merata yaitu $400 \mathrm{~kg} / \mathrm{ha}$ sampai $600 \mathrm{~kg} / \mathrm{ha}$.

Lahan di DAS ulu Selo memperlihatkan jumlah $\mathrm{P}_{2} \mathrm{O}_{5}$ yang relatif rendah bila dibandingkan dengan tanah dari DAS sumpur. Kenagarian Gurun yang terletak di Lereng tengah vulkanik memiliki nilai $\mathrm{P}_{2} \mathrm{O}_{5}$ yang paling rendah bila dibandingkan dengan jumlah unsur hara yang lain Hal yang sama terlihat pada unsur nitrogen. Simpurut yang terletak di lereng bawah volkanik memperlihatkan bahwa lahan sawah didaerah itu memiliki cadangan nitrogen yang lebih rendah bila dibandingkan dengan tanah di tempat lain. .

Kondisi cadangan hara pada persawahan yang terletak di DAS Sumpur dan DAS ulu Selo memperlihatkan bahwa tanah cukup kaya dengan cadangan hara untuk memproduksi tanaman. Hal ini juga ditunjang oleh nilai Kapasitas Tukar kation (KTK) dan Kejenuhan Basa (KB) yang juga menentukan kesuburan tanah sawah. Detail informasi disajikan pada tabel 5.

Tanah pada lereng bawah vulkanik yang terlihat pada data dari Simpurut memperlihatkan nilai KB yang rendah bila dibandingkan dengan tanah dari lokasi lokasi lain. Sedangkan tanah pada fihiografi Aluvial yang di wakili oleh DAS Sumpur memperlihatkan nilai $\mathrm{KB}$ yang tinggi yang nilainya berkisar antara 42 sampai 55 . Total kation basa pada tanah yang dipersawahkan juga lebih tinggi bila dibandingkan dengan data dari DAS Sumpur Pasaman.

Secara umum dapat dilihat bahwa kodisi yang menyokong terbentuknya kesuburan tanah yang tinggi antara lain $\mathrm{pH}$, Bahan organik, KTK, KB, dan Total kation basa berada pada kondisi yang optimal bagi serapan unsur hara oleh tanaman.

Tabel 6 memperlihatkan jumlah unsur hara dari tanah yang hilang pada suatu wilayah. Perhitungan ini lebih dimaksudkan untuk menambah jumlah nutrisi yang berperan sebagai nutrisi utama. Wisaksono ( 1953) memberikan perhatian penuh pada semua unsur yang menyokong pertumbuhan dan produksi padi salah satunya adalah silika, sedangkan Goswami dan Banerje memberikan perhatian kepada rasa nasi dari hasil panen. karena itu Goswami dan Banerje memasukan unsur belerang sebagai sesuatu yang penting sebagai unsur yang terbawa panen, sedangkan Wisaksono menambahkan dengan kebutuhan silika pada tanaman padi.

Tabel 5. Rata rata total kation Kejenuhan basa dan Kapasitas tukar kation

\begin{tabular}{|l|l|l|l|l|l|l|l|}
\hline lokasi & kedalaman & total kation & \multicolumn{3}{l|}{ K B } & \multicolumn{2}{l|}{ KTK } \\
\hline & & rata rata & sd & rata-rata & sd & rata rata & sd \\
\hline Pd Laweh & $0-20$ & 5.58 & 0.73 & 25.03 & 6.2 & 23.71 & 7.08 \\
\hline & $20-40$ & 6.06 & 0.56 & 30.19 & 13.96 & 22.98 & 7.98 \\
\hline Gurun & $0-20$ & 6.42 & 0.73 & 20.24 & 4.84 & 33.04 & 6.99 \\
\hline & $20-40$ & 6.57 & 0.69 & 23.72 & 3.92 & 28.2 & 4.37 \\
\hline Simpurut & $0-20$ & 7.98 & 0.53 & 18.54 & 3.4 & 44.64 & 10.07 \\
\hline & $20-40$ & 7.53 & 1.09 & 22.24 & 12.18 & 40.29 & 14.42 \\
\hline Lundar & $0-20$ & 7.99 & 1.36 & 44.09 & 15.75 & 19.08 & 3.78 \\
\hline & $20-40$ & 6.86 & 2.43 & 40.86 & 10.74 & 16.84 & 3.23 \\
\hline petok & $0-20$ & 9.57 & 1.4 & 55.48 & 8.17 & 17.55 & 3.29 \\
\hline & $20-40$ & 9.59 & 0.88 & 54.67 & 9.4 & 17.97 & 3.13 \\
\hline Kuamang & $0-20$ & 7.46 & 1.85 & 42.85 & 13.54 & 18.49 & 5.47 \\
\hline & $20-40$ & 6.9 & 1.68 & 42.81 & 9.8 & 16.47 & 3.42 \\
\hline
\end{tabular}


Tabel 6. Jumlah hara terangkut tanaman padi setiap musim tanam

\begin{tabular}{|c|c|c|c|c|c|c|c|}
\hline Unsur hara & $\begin{array}{l}\text { biji+ } \\
\text { jerami1t/ha a) }\end{array}$ & $6 \mathrm{t} / \mathrm{ha}$ a) & $\begin{array}{l}3.4 \mathrm{t} / \mathrm{ha} \\
\text { b) }\end{array}$ & $\begin{array}{l}2.4 \mathrm{t} / \mathrm{ha} \\
\text { c) }\end{array}$ & $\begin{array}{l}\text { jerami } \\
\text { c) }\end{array}$ & $8 \mathrm{t} / \mathrm{ha} \mathrm{d})$ & $\begin{array}{l}\text { jerami } \\
\text { f) }\end{array}$ \\
\hline $\begin{array}{l}\mathrm{K}_{2} \mathrm{O} \text { kg.ha- } \\
1\end{array}$ & $19.36-20.57$ & 150 & 60 & 12 & 52 & 141 & 126 \\
\hline${ }_{1}^{\mathrm{P}_{2} \mathrm{O}_{5} \mathrm{~kg} \cdot \mathrm{ha}^{-}}$ & $6.87-25.19$ & 45 & 55 & 12 & 11 & 129 & 18 \\
\hline $\mathrm{N} \mathrm{kg} \cdot \mathrm{ha}^{-1}$ & $16-24$ & 120 & 54 & 25 & 23 & 127 & 45 \\
\hline $\mathrm{CaO}$ & $8.4-9.8$ & 56 & & 2 & 13 & 75 & 28 \\
\hline $\mathrm{MgO}$ & 8.31 & 50 & & 4 & 6 & 67 & 53 \\
\hline $\mathrm{SO}_{4}^{2-}$ & 3.9 & 24 & & & & 31 & \\
\hline $\mathrm{SiO}_{2}$ & & & & 149 & 94 & 496 & 514 \\
\hline
\end{tabular}

a) Goswami and Banerjee 1978, b) Syss et. All 1993, c) Wisaksono 1953

d) Perhitungan kehilangan bila dilaporkan oleh petani, f) Patnaik 1978

Tabel 7. Cadangan Hara $\mathrm{N}, \mathrm{P}_{2} \mathrm{O}_{5}$, dan $\mathrm{K}_{2} \mathrm{O}$ pada lapisan atas tanah sawah di DAS Batang Sumpur dan DAS Ulu Selo

\begin{tabular}{|c|c|c|c|c|c|}
\hline lokasi & Unsur hara & rata-rata & $\mathrm{sd}$ & $8 \mathrm{t} / \mathrm{ha}$ & $4.5 \mathrm{t} / \mathrm{ha}$ \\
\hline Lundar & $\mathrm{K}_{2} \mathrm{O}$ kg.ha ${ }^{-1}$ & 571 & 127 & 141 & 79 \\
\hline \multirow[t]{2}{*}{$\mathrm{n}=11$} & $\mathrm{P}_{2} \mathrm{O}_{5}$ kg.ha $^{-1}$ & 198 & 89 & 129 & 73 \\
\hline & ${\mathrm{N} \mathrm{kg} \cdot \mathrm{ha}^{-1}}^{-1}$ & 363 & 288 & 127 & 71 \\
\hline Kuamang & $\mathrm{K}_{2} \mathrm{O}$ kg.ha ${ }^{-1}$ & 469 & 115 & 141 & 79 \\
\hline \multirow[t]{2}{*}{$\mathrm{n}=11$} & $\mathrm{P}_{2} \mathrm{O}_{5} \mathrm{~kg} \cdot \mathrm{ha}^{-1}$ & 188 & 73 & 129 & 73 \\
\hline & ${\mathrm{N} \mathrm{kg} \cdot \mathrm{ha}^{-1}}^{-1}$ & 261 & 164 & 127 & 71 \\
\hline Petok & $\mathrm{K}_{2} \mathrm{O}$ kg.ha ${ }^{-1}$ & 318 & 141 & 141 & 79 \\
\hline \multirow[t]{2}{*}{$\mathrm{n}=11$} & $\mathrm{P}_{2} \mathrm{O}_{5} \mathrm{~kg} \mathrm{ha}^{-1}$ & 169 & 82 & 129 & 73 \\
\hline & ${\mathrm{N} \mathrm{kg} \cdot \mathrm{ha}^{-1}}^{-1}$ & 290 & 160 & 127 & 71 \\
\hline Pd Laweh & $\mathrm{K}_{2} \mathrm{O}$ kg.ha ${ }^{-1}$ & 431.9 & 173.22 & 141 & 79 \\
\hline \multirow[t]{2}{*}{$\mathrm{n}=11$} & $\mathrm{P}_{2} \mathrm{O}_{5} \mathrm{~kg} \cdot \mathrm{ha}^{-1}$ & 58.27 & 12.63 & 129 & 73 \\
\hline & ${\mathrm{N} \mathrm{kg} \cdot \mathrm{ha}^{-1}}^{-1}$ & 255 & 54.95 & 127 & 71 \\
\hline Gurun & $\mathrm{K}_{2} \mathrm{O}$ kg.ha ${ }^{-1}$ & 280.36 & 204.07 & 141 & 79 \\
\hline \multirow[t]{2}{*}{$n=11$} & $\mathrm{P}_{2} \mathrm{O}_{5}$ kg.ha $^{-1}$ & 23.16 & 6.09 & 129 & 73 \\
\hline & ${\mathrm{N} \mathrm{kg} \cdot \mathrm{ha}^{-1}}^{-1}$ & 255.36 & 97.64 & 127 & 71 \\
\hline Simpurut & $\mathrm{K}_{2} \mathrm{O} \mathrm{kg} \cdot \mathrm{ha}^{-1}$ & 181.18 & 96.24 & 141 & 79 \\
\hline \multirow[t]{2}{*}{$\mathrm{n}=11$} & $\mathrm{P}_{2} \mathrm{O}_{5} \mathrm{~kg} \cdot \mathrm{ha}^{-1}$ & 58.73 & 17.47 & 129 & 73 \\
\hline & $\mathrm{N} \mathrm{kg} \cdot \mathrm{ha}^{-1}$ & 179.55 & 61.48 & 127 & 71 \\
\hline
\end{tabular}


Silika menjadi unsur hara yang penting bagi tanaman padi di Indonesia ( Wisaksono 1953) terutama untuk penguat batang dan jerami yang memiliki kadar silika yang tinggi. Walaupun silika tidak ditambahkan ke sawah dengan melakukan penambahan sebagaimana pupuk buatan lainnya, tapi dalam praktek pertanaman padi pemberian silika dilakukan melalui pemberian abu sekam, sekam padi yang dibusukan di tempat pengolahan gabah, dan pengembalian jerami ke sawah. Selain dari itu air irigasi yang berasal dari aliran kecil di lereng gunung juga memiliki kandungan silika. Di DAS Gunung Gadut kadar silika dalam air sungai sebagai hasil pelapukan batuan andesit adalah 16 ppm. (Rasyidin, dan Wakatsuki 1994)

Berdasarkan nilai kandungan hara tanah pada tabel. 4 maka dapatlah di perkirakan kemampuan lahan sawah pada DAS yang terletak di fishiografi Vulkanik yang di wakili oleh DAS Selo dan DAS yang berada pada sistim Aluvial yaitu DAS Sumpur. Perhitungan tersebut disajikan pada tabel 7.Dari tabel 7 dapat dilihat bahwa untuk menghasilkan gabah sebanyak $4.5 \mathrm{t} / \mathrm{ha}$ lahan persawahan di DAS Sumpur tidak memerlukan penambahan usur hara. Jumlah hara yang terbawa panen sebanyak $4.5 \mathrm{t} / \mathrm{ha}$ jauh lebih sedikit dari cadangan hara pada kedalam $0-20 \mathrm{~cm}$. Jumlah hara yang terbawa panen hanya berada pada nilai standard deviasi dari rata rata hasil analisis sampel pada setiap lokasi. Bahkan untuk menghasilkan sampai 8 t/ha lahan sawah di DAS ini masih kelebihan unsur hara. Itu belum termasuk unsur hara sebagai hasil pelapukan dan sedimentasi yang terjadi setiap tahunnya.

DAS Ulu Selo memperlihatkan ketidak seimbangan dalam jumlah fosfor untuk menghasilkan gabah 4.5t/ha. Sawah di DAS ini memerlukan tambahan fosfor sebanyak $15-50 \quad \mathrm{~kg} \quad \mathrm{P}_{2} \mathrm{O}_{5} / \mathrm{ha}$ untuk mengeimbangi hara yang dibutuhkan tanaman guna menghasilkan gabah $4.5 \mathrm{t} / \mathrm{ha}$. Untuk mendapatkan hasil sebanyak 8t/ha persawahan di DAS ini masih memiliki hara nitrogen dan Kalium yang cukup kecuali unsur fosfor yang membutuhkan tambahan 50-100 kg $\mathrm{P}_{2} \mathrm{O}_{5} / \mathrm{ha}$.

\section{KESIMPULAN DAN SARAN}

Berdasarkan hasil analisis tanah dan kebutuhan tanaman ternyata bahwa daerah persawahan pada setiap lokasi Daerah Aliran Sungai membutuhkan usur hara yang spesifik. Dengan kata lain bahwa tidak semua unsur hara yang harus ditambahkan kewilayah tersebut. Daerah yang selalu mendapat tambahan bahan baru gunung api baik melalui air banjir seperti yang di dapat di DAS Sumpur atau dari bahan erupsi berupa abu kepudan secara alamiah memiliki kesuburan alamiah yang tetap.

Usaha pemberian pupuk buatan dengan menggunakan rekomendasi umum pemupukan adalah suatu usaha yang bersifat tidak ekonomis, dan bahkan cendrung merusak lingkungan seperti terjadinya penurunan nilai $\mathrm{pH}$ yang di observasi di DAS Ulu Selo.

\section{DAFTAR PUSTAKA}

Ade Intan Kemala, 2000 Status Hara Utama NPK dan bahan Organik di Daerah Sentral Pertanaman Padi di DAS Ulu Selo Kabupaten Tanah Datar, Skripsi Fakultas Pertanian Unand Padang.

Afridia Husna, 2003. Pengaruh kombinasi Takaran Zeolit dan Pupuk Kandang Terhadap Kadar Fe Ultisol Tanah Sawah Bukaan Baru, Skripsi Fakultas Pertanian Unand Brady, NC. 1992 The nature and Properties of Soils.

Desaunette, 1977. Catalog of Landform of Indonesia, Soil Research Institute Bogor.

Fitria Rachmawati, 2001. Evaluasi Kesuburan Tanah pada Sentra pertanaman Padi di DAS Ulu Selo kabupaten Tanah Datar, Skripsi Fakultas Pertanian Unand

Goswami, N.N. and Banerjee, N.K. 1978, Phosphor, potassium and other macro elements. In Soils and Rice, International Rice Research Institut, Los Banos Laguna, Philippines 
Mc Lean.E.O, 1987. Soil $\mathrm{pH}$ and Lime requirement. In Page, A.L. Miller R.H, and Keeney D.R. Method of Soil Analysis, American Society of America, Soil Science Society of America, Number 9. Part 2 Agronomy, Madison Wisconsin U.S.A.

Nelson,D.W. and Sommer L.E, 1987. Total Carbon, Organic Carbon and Organic Matter. in Page, A.L. Miller R.H, and Keeney D.R. Method of Soil Analysis, American Society of America, Soil Science Society of America, Number 9. Part 2 Agronomy,

Odelman, L.R. Irsal las and SN Darwis, 1979. An Agroclimatic Map of Sumatra. Central Research Institute for Agriculture, Bogor Indonesia.

Olsen, S.R. and Sommers L.E, 1987. in Page, A.L. Miller R.H, and Keeney D.R. Method of Soil Analysis, American Society of America, Soil Science Society of America, Number 9. Part 2 Agronomy, Madison Wisconsin U.S.A.

Patnaik, S. 1978. Natural source of nutrients in rice soils, In Soils and Rice, International Rice Research Institut, Los Banos Laguna Philippines Ponnamperuma, 1978. Electrochemical Change in Submerged Soils and the Growth of Rice. In Soils and Rice, International Rice Research Institut, Los Banos Laguna Philippines

Rasyidin, A 2002. Pengaruh Manusia Terhadap Degradasi lahan, journal Penelitian Andalas no38/Mei/tahun XIV/2002 Rasyidin, $A$ and Wakatsuki T. 1994. The characterization of Precipitation and River

Water Chemistry of Iu River Watershed Southwestern Japan for Measuring Rates of Weathering and Soil Formation. Soil SSci.Plant Nutr. 40(2),319-332).
Resmi Sari Pribadi, 2003. Mobilitas Fe, dan Mn pada Tanah Sawah di DAS Mangau, Skripsi Fakultas pertanian Unand

Rhoades, J.D. 1987. Cation Exchange Capacity. in Page, A.L. Miller R.H, and Keeney D.R. Method of Soil Analysis, American Society of America, Soil Science Society of America, Number 9. Part 2 Agronomy, Madison Wisconsin U.S.A.

Zulfa Hanim, 2002. Status Hara utama NPK dan Bahan Organik Pada sentra Pertanaman Padi Sawah di DAS Batang Sumpur Kecamatan Panti Kabupaten Pasaman. Skripsi Fakultas Pertanian Unand

Sys, C. Van Rants,E. Debaveye, J. Beernaert, F. 1993 Land evaluation part III Crop Requirement. ITC for Graduate Soil Science University Gent Belgium

Soeprartohardjo, M. And Suhardjo, H. 1978 Rice Soils of Indonesia, in Soils and Rice.

Thomas G.W. 1987. Exchangeable Cations, in Page, A.L. Miller R.H, and Keeney D.R. Method of Soil Analysis, American Society of America, Soil Science Society of America, Number 9. Part 2 Agronomy, Madison Wisconsin U.S.A.

Upit Fitriani, 2002. Evaluasi kesuburan Tanah Pada Sentra Penanaman Padi Sawah di DAS Batang Sumpur Kecamatan Panti Kabupaten Pasaman

Verstappen, H.Th. 1973. A geomorphological Reconnaisance of Sumatra and Adjacent Islands ( Indonesia). Walter Noordhoff Publishing Gronigen The Netherland.

Wakatsuki, T. Saidi,A, Rasyidin, A. 1986. Soil in the Toposequence of G.gadut Tropical Rain. The South East Asian Studies, Kyoto University

Wisaksono. W.M, 1953. Ilmu Tubuh Tanah, Nodorkolff, N.V, Jakarta 